\title{
Effects of Impurities Content (Oxygen, Carbon, Nitrogen) on Microstructure and Phase Transformation Temperatures of Near Equiatomic TiNi Shape Memory Alloys
}

\author{
P. Olier, F. Barcelo*, J.L. Bechade*, J.C. Brachet*, E. Lefevre** and G. Guenin*** \\ CEA/CEREM/CE2M, CEA Saclay, 91191 Gif-sur-Yvette cedex, France \\ * CEA/CEREM/SRMA, CEA Saclay, 91191 Gif-sur-Yvette cedex, France \\ ** CEA/INSTN/SEPEM, CEA Saclay, 91191 Gif-sur-Yvette cedex, France \\ *** GEMPPM/INSA de Lyon, 69621 Villeurbanne cedex, France
}

\begin{abstract}
Investigation of precipitation is performed on several near equiatomic TiNi alloys elaborated by arc melting or by powder metallurgy (combustion synthesis mode). These alloys contain various amount of impurities (oxygen, carbon, nitrogen). We show that such impurities result in both oxides $\left(\mathrm{Ti}_{4} \mathrm{Ni}_{2} \mathrm{O}_{\mathrm{x}}\right.$, with $\left.\mathrm{x} \leq 1\right)$ and carbonitrides $\left(\mathrm{TiC}_{\mathrm{x}} \mathrm{N}_{1-\mathrm{x}}\right.$, with $\left.\mathrm{x} \leq 1\right)$ precipitation. X-ray diffraction measurements are performed on residues of electrochemical extraction to determine the structure and the lattice parameters of these precipitates. The precipited fractions are quantified for various amount of impurities by image analysis. A very good correlation is obtained between the nominal content of impurities determined by chemical analysis and the precipited fraction measured by image analysis and $\mathrm{X}$-ray measurements. Our results indicate that almost all the nominal oxygen has precipited to form $\mathrm{Ti}_{4} \mathrm{Ni}_{2} \mathrm{O}$ type oxides.

As a consequence, an increase of the impurities content in near equiatomic TiNi alloys implies a lowering of the phase transformation temperatures. This phenomenon is attributed to the precipitates stoichiometry which induces a deficit of titanium content in solid solution.. On the other hand, we find that fine precipitation improve the grain size reduction during hot working. Possible explanation is that the precipitates act as grain refiners through a "pinning" or a "grinding" process.
\end{abstract}

\section{INTRODUCTION}

It is known that oxygen constitutes one of the major impurity in TiNi shape memory alloys (SMA). Some studies have shown that this impurity conducts to a finely dispersed secondary precipitated phase within the TiNi matrix. A survey of literature indicate that it would be caused by an oxide precipitation and a stoichiometry of $\mathrm{Ti}_{4} \mathrm{Ni}_{2} \mathrm{O}_{\mathrm{x}}$ (with $\mathrm{x} \leq 1$ ) is suggested $[1][2][3][4]$. Due to the lack of oxygen segregation in solid solution, no embrittling effect have been reported for low nominal oxygen content $(\leq 1200 \mathrm{ppm})$ [4]. It appears that other contaminants such as carbon and nitrogen may be also responsible for the presence of secondary precipitated phase in the matrix [1][2].

The aim of this paper is to characterize the precipitation by different and complementary analysis techniques. Our study is also devoted to have a better understanding of the role of these impurities in respect with phase transformation temperatures and microstructure (grain size).

\section{EXPERIMENTAL PROCEDURE}

Equiatomic NiTi alloys were obtained by two fabrication routes : Powder Metallurgy through combustion synthesis (PM) and arc melting (AM). The ingots were subsequently hot-worked by extrusion (for PM products) or by rolling (for AM products). Samples taken from the extruded rods or from the rolled sheet were homogeneized a $900^{\circ} \mathrm{C}$ for annealing time ranging from 24 up to 72 hours.

In order to understand the role of each impurity $(\mathrm{O}, \mathrm{C}, \mathrm{N})$ on the metallurgical properties, different nominal content were tested. The chemical analysis and the Ms temperature (determined by Differential Scanning Calorimetry) are given in Table 1. 
Table $1 /$ Impurities content and Ms temperatures

\begin{tabular}{|c|c|c|c|c|c|}
\hline & Fabrication route & $\%$ wt O & $\%$ wt C & \%wt N & $\mathrm{Ms}\left({ }^{\circ} \mathrm{C}\right)$ \\
\hline M1 & $\mathrm{AM}+$ hot rolling & $0.016+1-0.001$ & $0.006+1-0.001$ & $0.002+1-0.001$ & 72 \\
\hline $\mathrm{M} 2$ & AM + hot rolling & $0.062+/-0.002$ & $0.012+1-0.002$ & $0.018+1-0.001$ & 50 \\
\hline PI & PM + hot extrusion & $0.060+1-0.002$ & $0.034+/-0.002$ & $0.001+1-0.001$ & 57 \\
\hline P2 & PM + hot extrusion & $0.12+1-0.01$ & $0.059+1-0.002$ & $0.002+1-0.001$ & 38 \\
\hline
\end{tabular}

\section{CHARACTERIZATION OF THE PRECIPITATION}

\subsection{X-Ray measurements}

Investigation of precipitation was conducted on both alloys elaborated by PM route by using $\mathrm{X}$-ray measurements. The extraction of the precipitates from the matrix was successfully performed in an electrolytic cell. X-ray diffraction was performed by X-ray diffractometer using $\mathrm{Cu} \mathrm{K} \alpha$ radiation. Conditions of the electrochemical extraction procedure are detailed in [1]. Figure 1 shows the X-ray diffraction pattern of extracted precipitates for P1 and P2 alloys.

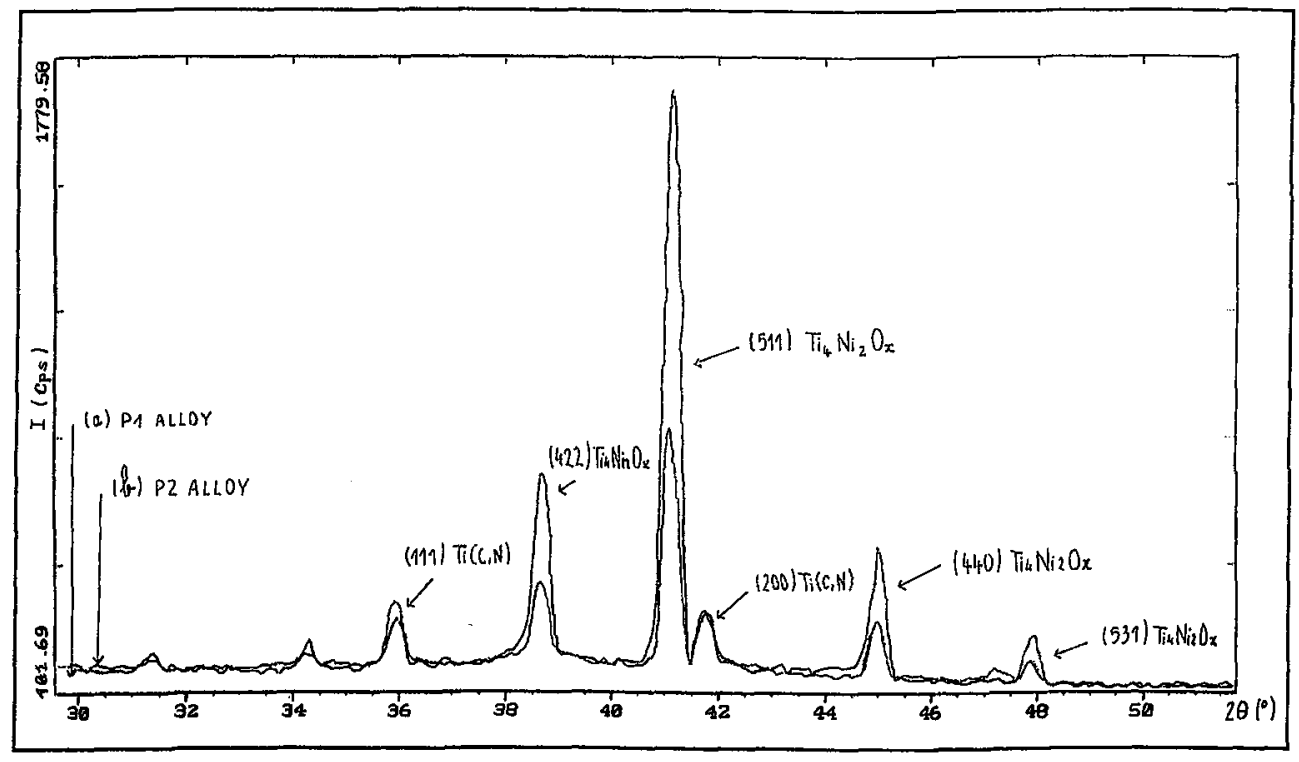

Figure 1 : X-Ray diffraction pattem performed on extracted precipitates

(a) $\mathrm{PI}$ alloy (600ppm $\mathrm{O}_{2}, 340 \mathrm{ppm} \mathrm{C}$ ) - (b) $\mathrm{P} 2$ alloy (1200ppm $\left.\mathrm{O}_{2}, 590 \mathrm{ppm} \mathrm{C}\right)$

Two types of precipitates have been identified on these alloys : The major one is of $\mathrm{Ti}_{4} \mathrm{Ni}_{2} \mathrm{O}$ type oxide ${ }^{1}$, the second one is titanium carbonitride $\operatorname{Ti}(C, N)$. These both precipitates exhibit FCC crystal structure. Complementary investigations have shown that AM products (M1 and M2) only contain oxide precipitates.

The lattice parameters were calculated from the 5 most intensive Bragg reflexions of the X-ray diffraction pattern. A lattice parameter of : $a_{0}=1,1362 \mathrm{~nm}(+/-0,0007)$ was found for $\mathrm{Ti}_{4} \mathrm{Ni}_{2} \mathrm{O}$ (this experimental value is quite closed to the value reported in the literature by Mueller and al

\footnotetext{
${ }^{1}$ Some complementary experiments using electron energy loss spectroscopy [6] have confirmed the oxygen incorporation in precipitates
} 
(i.e. $\left.a_{0}=1,1328 \mathrm{~nm}\right)$ [7]. A lattice parameter of : $a_{0}=0,4320 \mathrm{~nm}(+/-0,0007)$ was found for the titanium carbonitride precipitates. By comparing this last experimental value to those of the literature $\left(a_{0}(\mathrm{TiC})=0,433 \mathrm{~nm}\right.$ and $\left.\mathrm{a}_{0}(\operatorname{TiN})=0,424 \mathrm{~nm}\right)$, one can estimate the respective content in carbon and nitrogen in the precipitate by a linear extrapolation. The following stoichiometry is obtained : $\operatorname{Ti}\left(\mathrm{C}_{0,9} \mathrm{~N}_{0,1}\right)$.

From the X-ray spectra, it is apparent that the peak intensity ratio $I_{T(C, N)} / I_{\text {Ti4Ni2o }}$ is quite different for the both $\mathrm{P} 1$ and $\mathrm{P} 2$ alloys. Assuming proportionality between the chemical concentration and the peak intensity (no texture effects), it is possible to calculate the $\mathrm{Ti}_{4} \mathrm{Ni}_{2} \mathrm{O}$ and $\mathrm{Ti}(\mathrm{C}, \mathrm{N})$ precipitate volumic fraction ratio for the both alloys.

$$
\begin{aligned}
& \mathrm{C}_{\mathrm{Ti} 4 \mathrm{Ni2O}}+\mathrm{C}_{\mathrm{Ti}(\mathrm{C}, \mathrm{N})}=1 \\
& \mathrm{C}_{\mathrm{Ti} 4 \mathrm{Ni2O}} / \mathrm{C}_{\mathrm{Ti}(\mathrm{C}, \mathrm{N})}=\mathrm{f}_{\mathrm{Ti} 4 \mathrm{Ni} 2 \mathrm{O}} \cdot \mathrm{I}_{\mathrm{Ti} 4 \mathrm{Ni} 2 \mathrm{O}} / \mathrm{f}_{\mathrm{Ti}(\mathrm{C}, \mathrm{N})} \cdot \mathrm{I}_{\mathrm{Ti}(\mathrm{C}, \mathrm{N})}=\mathrm{k}
\end{aligned}
$$

(f represent the atomic diffusion factor)

$(1)+(2) \Longrightarrow C_{\text {Ti4Nizo }}=\mathrm{k} /(1+\mathrm{k}), \mathrm{C}_{\mathrm{Ti}(\mathrm{C}, \mathrm{N})}=1 /(1+\mathrm{k})$,

This calculation is made for each X-ray spectrum by using the maximal X-ray peak intensity which corresponds to the (511) peak for $\mathrm{Ti}_{4} \mathrm{Ni}_{2} \mathrm{O}$ and (200) peak for $\mathrm{Ti}(\mathrm{C}, \mathrm{N})$. Results are reported on Table 2 .

Table $2 / \mathrm{Ti}_{4} \mathrm{Ni}_{2} \mathrm{O}$ and $\mathrm{Ti}(\mathrm{C}, \mathrm{N})$ precipitate valumic fraction ratio in both $\mathrm{PI}$ and $\mathrm{P} 2$ alloys

\begin{tabular}{|c|c|c|}
\hline Alloy & $\mathrm{P} 1$ & $\mathrm{P} 2$ \\
\hline \hline $\mathrm{C}_{\mathrm{Ti} \text { i Nizo }} / \mathrm{C}_{\mathrm{Ti}(\mathrm{C}, \mathrm{N})}$ ratio (from X-ray measurements) & 11,5 & 4,3 \\
\hline
\end{tabular}

\subsection{Quantification of the precipitates by taking account of the chemical analysis of nominal impurity content}

Results of chemical analysis give us the nominal content in oxygen for each alloys. If we consider a stoichiometry of $\mathrm{Ti}_{4} \mathrm{Ni}_{2} \mathrm{O}$ for the oxide, we can estimate the volumic ratio of $\mathrm{Ti}_{4} \mathrm{Ni}_{2} \mathrm{O}$ particles by using the following relation :

$$
f_{\text {volumic (Ti4Ni2O) }}=f_{\text {weight (Ti4Ni2O) }} *\left(\rho_{\text {TiNi }} / \rho_{\text {Ti4Ni2O }}\right)
$$

The density of TiNi is equal to $6.45 \mathrm{~g} / \mathrm{cm}^{3}$ [8]. The lattice parameter of the oxide is given by $\mathrm{X}$-ray measurements : $\mathrm{a}_{0}=1.1362 \mathrm{~nm}$. Calculation was made by assuming that all the oxygen dissolved in the equiatomic $\mathrm{TiNi}$ forms $\mathrm{Ti}_{4} \mathrm{Ni}_{2} \mathrm{O}$ type oxides. By analogy, we can also determine the volumic ratio of $\mathrm{Ti}(\mathrm{C}, \mathrm{N})$ precipitates in the $\mathrm{PM}$ alloys. For this calculation, we can assume that the nitrogen content in the precipitate is not significant with respect to the carbon content. The density of $\mathrm{TiC}$ compound is equal to $: 4,97 \mathrm{~g} / \mathrm{cm}^{3}$. If we assume that all the carbon dissolved in the equiatomic TiNi forms TiC type carbides, we can predict the volumic ratio of the precipitates in the alloys.

Results are reported in Table 3 . If we compare the $\mathrm{C}_{\text {(Ti4Ni2O) }} / \mathrm{C}_{\text {(TiC) }}$ ratio calculated here with the same one obtained by X-ray (Table 2), we note a good correlation for P2 but not for P1 alloy.

Table 3 / Volumic fraction of oxides and carbides calculated on the basis of the chemical analysis. data (With the assumption that all the nominal oxygen and carbon atoms have precipitated)

\begin{tabular}{|l|c|c|c|c|}
\hline \multicolumn{1}{|c|}{ Alloy } & M1 & M2 & P1 & P2 \\
\hline Volumic fraction of $\mathrm{Ti}_{4} \mathrm{Ni}_{2} \mathrm{O}(\%)$ & $\mathbf{0 , 3 6} \pm \mathbf{0 , 0 2}$ & $\mathbf{1 , 3 8} \pm \mathbf{0 , 0 4}$ & $\mathbf{1 , 3 3} \pm \mathbf{0 , 0 4}$ & $\mathbf{2 , 6 \pm 0 , 2}$ \\
\hline Volumic fraction of $\mathrm{TiC}(\%)$ & $\mathbf{0}$ & $\mathbf{0}$ & $\mathbf{0 , 3 5} \pm \mathbf{0 , 0 2}$ & $\mathbf{0 , 6 1} \pm \mathbf{0 , 0 2}$ \\
\hline $\mathrm{C}\left(\mathrm{Ti}_{4} \mathrm{Ni}_{2} \mathrm{O}\right) / \mathrm{C}(\mathrm{TiC})$ ratio & & & $\mathbf{3 , 8}$ & $\mathbf{4 , 3}$ \\
\hline
\end{tabular}




\subsection{Contribution of the Image Analysis}

A basic description of the precipitates is performed by using image analysis techniques (TRACOR 8500-7500). Samples for analysis were mechanically polished and observed in the longitudinal and transverse direction by SEM using backscattering electron mode.

For each sample, the analysed surface varies from 0,3 to $1 \mathrm{~mm}^{2}$. The finest analyzed particles have a minimal diameter of $0,1 \mu \mathrm{m}$ (pixel size). Results concerning the size distribution and the surfacic fraction of both $\mathrm{Ti}_{4} \mathrm{Ni}_{2} \mathrm{O}$ and $\mathrm{Ti}(\mathrm{C}, \mathrm{N})$ precipitates are reported in Table 4 . The surface ratio of precipitates $\left(\mathrm{Ti}_{4} \mathrm{Ni}_{2} \mathrm{O}\right.$ type) is plotted against the range of diameter for each alloy (M1, M2, P1,P2) (fig. 2). From these results it is concluded that most of the precipitates have a typical diameter ranging from 0,25 up to $1,5 \mu \mathrm{m}$. It is clear that an increase of the nominal oxygen content promotes a reduction of the average size of the particles.

Table 4 / Size distribution and surfacic area of the precipitates included in different alloys containing various amount of imurities and observed in longitudinal and transverse direction

\begin{tabular}{|c|c|c|c|c|c|c|}
\hline Alloy & M1 & M2 & \multicolumn{2}{|c|}{ P1 } & \multicolumn{2}{|c|}{ P2 } \\
\hline Precipitate & $\mathrm{Ti}_{4} \mathrm{Ni}_{2} \mathrm{O}$ & $\mathrm{Ti}_{4} \mathrm{Ni}_{2} \mathrm{O}$ & $\mathrm{Ti}_{4} \mathrm{Ni}_{2} \mathrm{O}$ & $\mathrm{Ti}(\mathrm{C}, \mathrm{N})$ & $\mathrm{Ti}_{4} \mathrm{Ni}_{2} \mathrm{O}$ & $\mathrm{Ti}(\mathrm{C}, \mathrm{N})$ \\
\hline Magnification & 2000 & 2000 & $1000-2000$ & $1000-2000$ & $1000-4000$ & $1000-4000$ \\
\hline $\mathrm{Nb}$ of particles & 6003 & 18298 & 1262 & 239 & 1073 & 60 \\
\hline Surf. Fraction \% & 0.52 & 1.25 & 1.06 & 0.09 & 1.96 & 0.35 \\
\hline$\phi$ moy. $(\mathrm{Nb})$ & 1.27 & 0.78 & 0.90 & 0.73 & 0.52 & 1.30 \\
\hline$\phi$ moy. (Surf.) & 2.71 & 1.40 & 2.60 & 1.30 & 1.00 & 2.91 \\
\hline
\end{tabular}
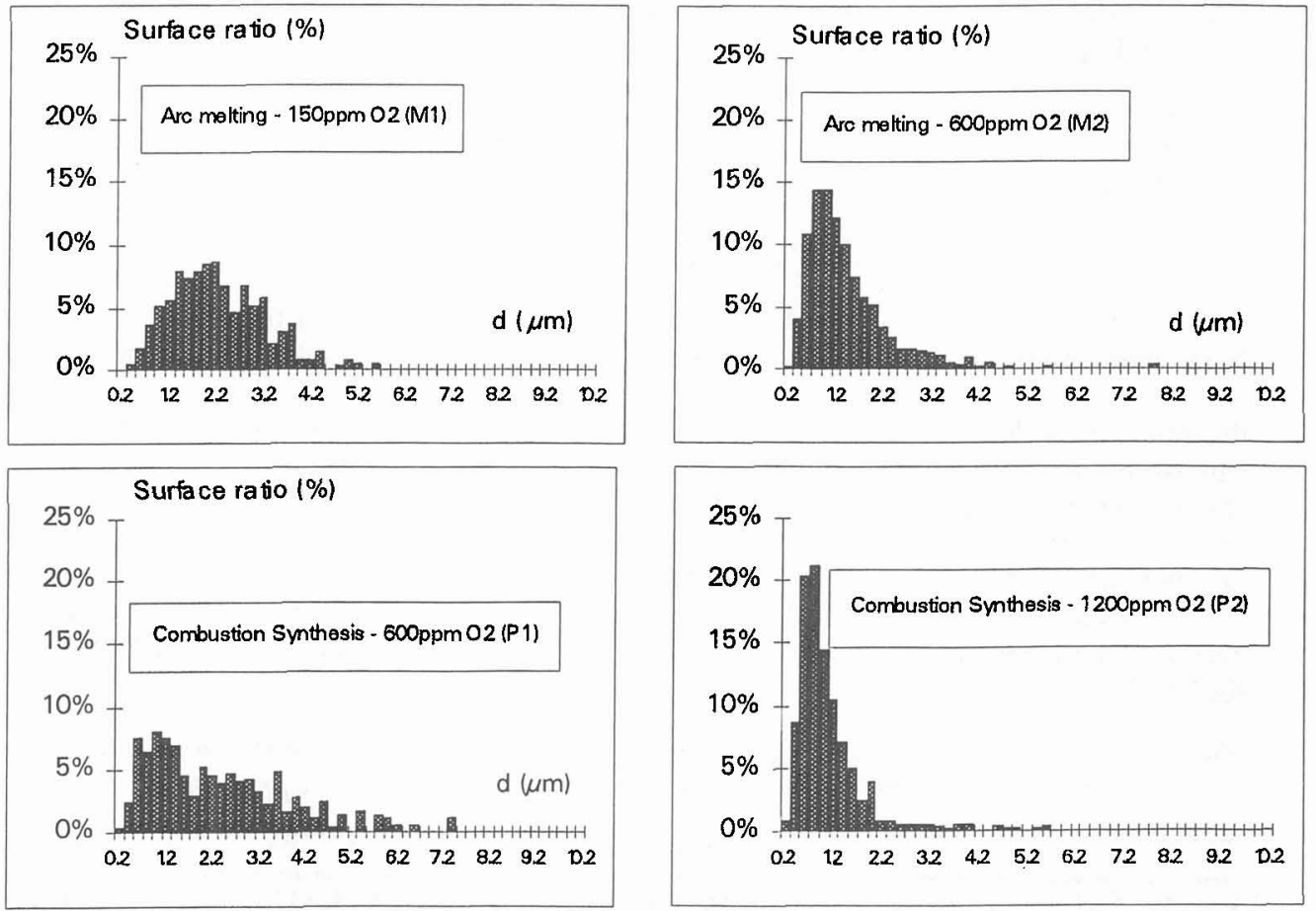

Figure 2 : Size distribution of the $\mathrm{Ti}_{4} \mathrm{Ni}_{2} \mathrm{O}$ precipitates for equiatomic $\mathrm{NiTi}$ alloys containing various amount of oxygen (observations in transverse direction only) 


\subsection{Discussion}

The presence of impurities such as $\mathrm{O}, \mathrm{C}, \mathrm{N}$ in equiatomic NiTi alloys induces $\mathrm{Ti}_{4} \mathrm{Ni}_{2} \mathrm{O}$ type and carbonitride $\mathrm{Ti}(\mathrm{C}, \mathrm{N})$ type precipitation. The nature and the structure of these precipitates was confirmed by $\mathrm{X}$-ray measurements. A quantification of the precipitate fraction was established by image analysis. The assumption that all the nominal oxygen content forms $\mathrm{Ti}_{4} \mathrm{Ni}_{2} \mathrm{O}$ seems to be confirmed by image analysis results. On the other hand, such an agreement between chemical analysis and image analysis is not obvious concerning carbon precipitation and it seems that part of this element is retained in solid solution $(\sim 0,025 \mathrm{wt} \%)$.

The comparison between calculations from chemcal analysis and image analysis investigations indicate a good agreement as it is shown on the figure 3 .

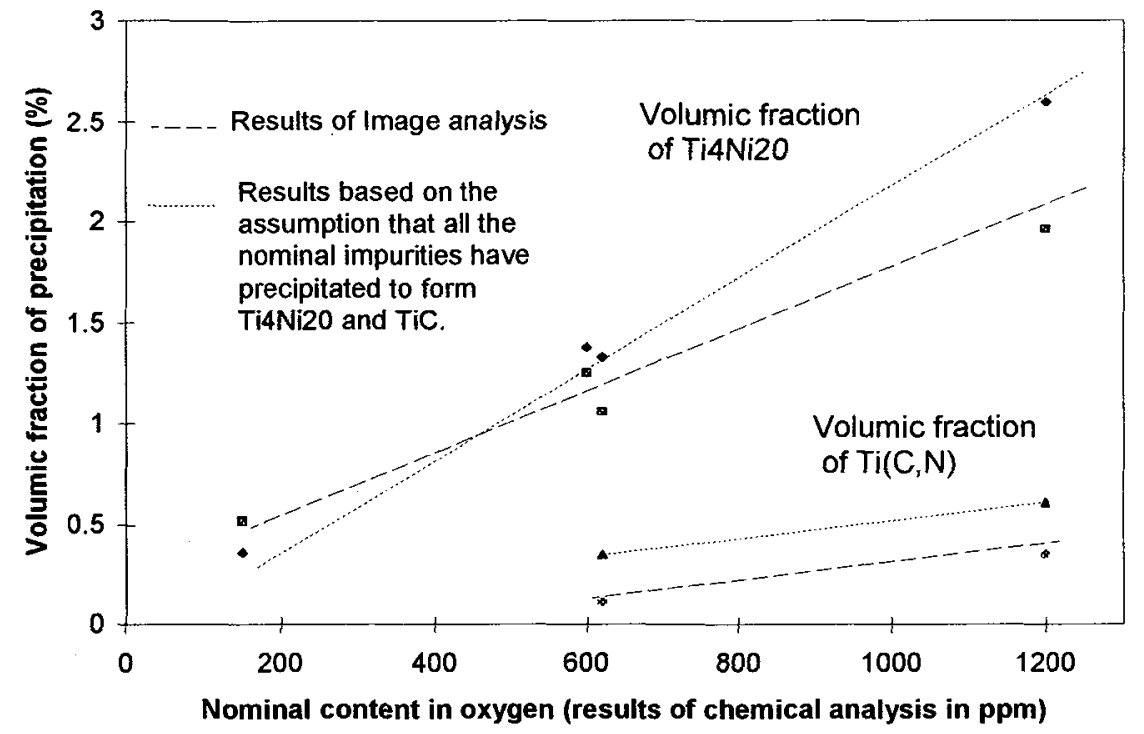

Figure 3 : Correlation between calculation from chemical analysis results (assuming that all the nominal oxygen and carbon atoms have precipitated) and image analysis investigations concerning the precipitated fraction of each phase

\section{INFLUENCE OF THE IMPURITIES ON BOTH PHASE TRANSFORMATION AND MICROSTRUCTURE (GRAIN SIZE)}

We have found that the precipitation have two main consequences which are significant in view of industrial applications. It is a matter of transformation temperatures and grain refinement.

\subsection{Consequence on phase transformation temperatures}

Due to the stoichiometry established for the oxide precipitate ("2" atoms of titanium for "1" atom of nickel), there is an increasing of the nickel content in solid solution. So, the nominal ratio $\mathrm{Ni} / \mathrm{Ti}=0,5 \%$ at. is not conserved in the matrix. A simple calculation allows to express the "true" nickel concentration in solid solution if we assume that all the oxygen dissolved in the equiatomic NiTi forms $\mathrm{Ti}_{4} \mathrm{Ni}_{2} \mathrm{O}$ type oxides. For arc melting mode, we obtain :

$\mathrm{C}_{\mathrm{Ni}}=100\left(50-2 \mathrm{x}_{0}\right) /\left(100-6 \mathrm{x}_{0}\right)$, $x_{0}$ represent the nominal content in oxygen (\%at.) 
The "true" nickel content in solid solution calculated by taking into account of the titanium incorporation in precipitates is given in table 5 .

According to some studies [9][10], increasing the nickel content induces a lowering of the typical phase transformation temperatures. Hanlon and al [10] have shown that there is a correlation between the $\mathrm{Ni}$ concentration and the transformation temperatures in $\mathrm{Ti}_{50-\mathrm{x}} \mathrm{Ni}_{50+\mathrm{x}}$ alloys (for $x$ ranging from 0 to 1 ). The values of Ms exptrapolated from [10] and our experimental values are both reported in table 5 . A quite good agreement is observed.

Table 5 / Relation between the nickel content in solid soution and the temperature $M_{s}$

\begin{tabular}{|c|c|c|c|c|}
\hline Alloy & M1 & M2 & P1 & P2 \\
\hline \hline $\mathbf{C}_{\mathrm{Ni}}$ (\%at.) & 50,05 & 50,20 & 50,22 & 50,48 \\
\hline $\mathbf{M}_{\mathrm{s}}$ expérimental value $\left({ }^{\circ} \mathrm{C}\right)$ & 72 & 50 & 55 & 38 \\
\hline $\mathrm{M}_{\mathrm{s}}$ extrapolated value[10] $\left({ }^{\circ} \mathrm{C}\right)$ & 53 & 43 & 44 & 26 \\
\hline
\end{tabular}

As a consequence, it appears clearly that by acting on impurities content control and on titanium concentration adjustment, one can obtain controlled and reproducible specific phase transformation temperatures which is of crucial interest in view of industrial applications.

\subsection{Consequence on microstructure (grain size)}

If we compare the microstructure of two alloys rolled at the same temperature $\left(850^{\circ} \mathrm{C}\right)$ with the same ratio of thickness reduction $(75 \%)$, we can notice that the grain size is quite dependant of the nominal content in oxygen (see fig. 4). Our observations (in transverse direction) indicate that oxide precipitation enhances the grain size refinement during the hot-working process. The final average grain size is about $100 \mu \mathrm{m}$ for the alloy containing $150 \mathrm{ppm} \mathrm{O}_{2}(\mathrm{M} 1)$, while it is about $65 \mu \mathrm{m}$ for the alloy containing $600 \mathrm{ppm} \mathrm{O}_{2}(\mathrm{M} 2)$.

One can suggest that $\mathrm{Ti}_{4} \mathrm{Ni}_{2} \mathrm{O}$ type oxides act on the grain size refinement through a pinning process at grain boundaries during dynamic recrystallization. An other possible interpretation would be a "grinding" of the austenitic grains during the hot-working. The observed decrease of the oxide size as a function of the nominal oxygen content increase is consistent with this last assumption.

\section{References}

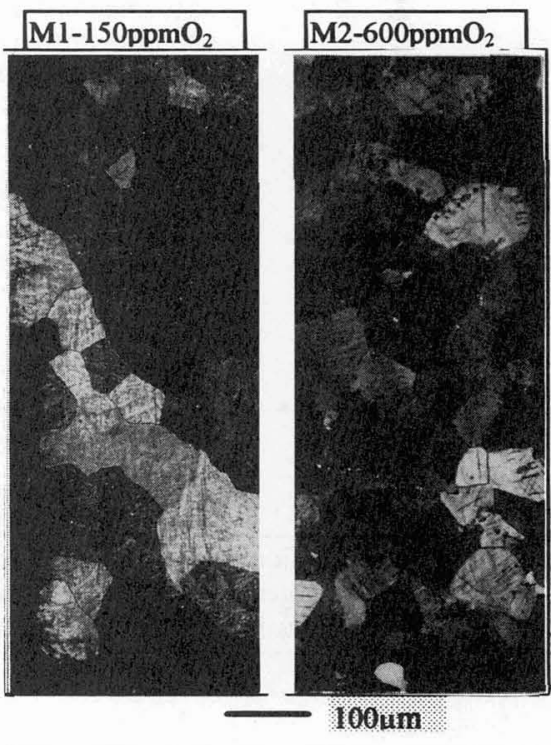

Figure 4: Microstructure of hot rollex samples (annealed $24 \mathrm{~h}$ at $900^{\circ} \mathrm{C}$ containing various amount of oxygen

[1] Olier P., Doctoral Thesis, Orsay University, 1995

[2] Rozner A.G. and al., Trans. Of the ASM, Techn. Notes, Vol. 58, 1965, pp. 415-418

[3] Uehara S., Sasano H., Suzuki T., Proc. TDA Ti Conf., 1982, p. 161

[4] Wasilewski R.J., Butler S.R.,Hanlon J.E., Metal Sc Journal, 1, 1967, p. 104

[5] Olier P., Brachet J.C., Guenin G., Proc. ESOMAT'94, J. de Phys. IV, Coll. C2, Vol. 5, 1995 , pp. 217-222

[6] Lefebvre E., CEA SACLAY, INSTN, unpublished data

[7] Mueller M.H., Knott H.W., Trans. Met. Soc. AIME, Vol. 277, 1963, pp. 674-678

[8] Jackson C.M and al, NASA SP 5110, 1972, p. 23

[9] Guenin G., Techn. de l'Ingénieur, Vol. M2-III, M530, pp. 1-12

[10] Hanlon J.E., Butler S.R., Wasilewski R.J., Trans. Met. Soc. of AIME, Vol. 239, 1967, p. 1326 